\title{
A study of role of bacterial vaginosis in preterm labour
}

\begin{abstract}
Background: Bacterial vaginosis is a common, complex clinical syndrome characterized by alterations in the normal vaginal flora. The aim of the study was to study the prevalence of bacterial vaginosis during late pregnancy (28-37 weeks).

Methods: We carried out a cross sectional study for a period of one year in which we tested for Bacterial Vaginosis in "patients" and "Control" patients, all hospitalized between 28-37 week of gestation. The protocol drafted before the study included several data collection forms; these enabled verifications of the inclusion and exclusion criteria for each patient. Just after inclusion, each patient underwent a gynaecological examination. After introduction of an unlubricated vaginal speculum, the examiner tested for Amsel's diagnostic criteria. The results of the examination were then provided to the physicians treating the patients.
\end{abstract}

Results: Age of Cases was in between 20 and 42 years and their mean age 29.7 \pm 4.2 years. Literacy rate in the Study group was $62.0 \%$ and was significantly low $(\mathrm{p}<0.05)$. Gestation Age (weeks) in the subjects of study group was in between 21 and 36 with the mean of $30.2 \pm 2.8$. Study/Control group did differ significantly $(\mathrm{p}<0.05)$ for Proportionate change in Previous H/O Intra Uterine Growth Retardation 35.4/15.9, Abortions 23.0/0.0 and PreTerm Delivery 17.0/0.0.

Conclusion: Gram stain in an easy and simple method of diagnosing bacterial vaginosis which can be used as an alternative to Amsel's criteria. High prevalence of bacterial vaginosis is found in women from low socioeconomic status.

Keywords: bacterial vaginosis, amsler's criteria, preterm labour, preterm delivery
Volume 4 Issue 3 - 2018

Tabassum Shaw,' Sheikh Mohd Saleem,' Shahida Mir, ${ }^{2}$ Muneer A Masoodi,' Muhammad Salim Khan $\mathrm{S}^{\prime}$

'Department of Community Medicine, Government Medical College, Srinagar

${ }^{2}$ Department of Gynecology and Obstetrics, Government Medical College, Srinagar

Correspondence: Sheikh Mohd Saleem, Department of community medicine, Government Medical College, Srinagar, JK, India,Tel 7006806993, Email saleem.900@gmail.com

Received: February 12, 2018 | Published: June 20, 2018

\section{Introduction}

The Bacterial vaginosis is a typical and complex clinical disorder which occurs due to alteration in the normal vaginal flora. It is the most widely recognized vaginal infection in women of child bearing age affecting $10 \%$ to $64 \%{ }^{1}$ of the female population at any given time. It has been related with variety of unfavourable health outcomes including endometritis; postpartum endometritis; non-gonococcal, non-chlamydial pelvic inflammatory disease ${ }^{2}$ and an increased risk of acquiring and transmitting HIV disease. ${ }^{3,4}$

Bacterial vaginosis is an inflammatory disorder in the vagina integrated with several forms of bacteria. Thus the overgrowth of normal bacteria in the vagina causes infection producing discharge. However, the new name Vaginosis, depict that number of bacteria species naturally host in the vagina with a compound growth. Gardenella $^{5}$ is the chief organism, whereas bacteriods, mobiluncus, Mycoplasma hominis, peptostreptococcus, fusobacterium and prevotella are other organisms responsible for causing bacterial vaginosis. The vaginal discharge is thin, typically white or grey with a fishy odour that is mainly observed after intercourse. Women with Bacterial vaginosis may also have burning sensation during urination or itching in and around the vagina, or both. Nonetheless, most women with Bacterial Vaginosis report without sign and symptoms and are diagnosed incidentally on vaginal examination or Pap's smear. Bacterial vaginosis is hazardous and causes disturbing symptoms. Any woman with an unusual discharge should be evaluated for serious infections such as chlamydia and gonorrhoea. It is caused by an imbalance of naturally occurring bacterial flora, and should not be confused with Trichomonas vaginitis trichomoniasis) or yeast infection (candidiasis). Bacterial vaginosis early in pregnancy is associated with both preterm delivery and late miscarriage. Bacterial vaginosis is one of the leading causes of preventable preterm labour. Women with bacterial vaginosis usually present with preterm labour ${ }^{6,7}$ encounter both untimely premature rupture of membrane (PROM $)^{8}$ and preterm premature rupture of membranes (PPROM) and have concomitant infections including amnionitis, postpartum endometritis and post caesarian wound infections. ${ }^{2,9}$ Successful oral treatment of Bacterial Vaginosis ${ }^{10,11}$ amid pregnancy diminishes the rate of preterm birth by $30 \%$ to $50 \%$. Preterm birth generally is a main cause of neonatal mortality and morbidity all over the world.

Keeping in view seeing the burden of Bacterial vaginosis and other associated factors, we conducted this study in one of the biggest Tertiary care hospital of Jammu \& Kashmir state with the following aim and objectives:

a. To study the prevalence of bacterial vaginosis during late pregnancy (28-37wks).

b. To perform a bacteriological study of vaginal smear.

c. To confirm the presence of bacterial vaginosis as a contributing factor for preterm labour.

\section{Methodology}

This was a cross sectional study which was carried out over a period of one year among all pregnant women hospitalized between the 28-37 week of gestation at Department of Gynaecology and Obstetrics, Government Lal Ded Hospital Srinagar Kashmir, allied to Government Medical College Srinagar. The study was carried out 
to test for Bacterial Vaginosis in pregnant patients who were referred as "Cases" for this study. The inclusion criterion for the cases was preterm labour, which we defined as repeated uterine contractions that required intravenous tocolysis and was severe in nature (i.e) the patient also had to have either a cervix dilatation of $\geq 2 \mathrm{~cm}$ on digital cervical examination or a history of spontaneous preterm delivery ( $<37$ weeks). We also included equal number of pregnant females who were referred as "Controls" in this study. The inclusion criterion for control patients was hospitalization for an obstetrical reason between 28-37 week of gestation including preeclampsia, intrauterine growth retardation, diabetes, cholestasis, maternal psychological disorders or for monitoring fetal wellbeing. Control group of patients were taken with a view to increase the power of the study, increase the sample size, comparative valuation and to reduce any potential confounding factors. Both the cases and controls were all hospitalized between the 28-37 week of gestation. Each patient in the case group was subsequently matched to a control patient in the same department, according to the gestational age at study inclusion ( \pm 2 weeks). The exclusion criteria were the same for both the groups: gestational age less than 28 or more than 34 weeks, local or general antibiotic therapy within the past 8 days, premature rupture of the membranes or suspected membrane leak, bleeding or any cause of preterm labour. The protocol drafted before the study included several data collection forms; these enabled verifications of the inclusion and exclusion criteria for each patient. Just after inclusion, each patient underwent a gynaecological examination. After introduction of an unlubricated vaginal speculum, the examiner tested for Amsel's diagnostic criteria as mentioned below: ${ }^{12}$

Three of four criteria must be met; it establishes accurate diagnosis of bacterial vaginosis in 90 percent of affected women.

a. Homogeneous vaginal discharge (colour and amount may vary).

b. Amine (fishy) odor when potassium hydroxide solution is added to vaginal secretions (commonly called the "whiff test").

c. Presence of clue cells (greater than $20 \%$ ) on microscopy.

\section{d. Vaginal $\mathrm{pH}$ greater than 4.5 .}

Three additional samples were taken at the cul de sac; two were used for culture, and the third wax wet- mounted for microscopy to search for clue cells and to calculate the Nugent score (counting relative proportion of bacterial morphotypes. ${ }^{4}$ The bacteriology examination was performed in the microbiological laboratory of the said hospital. The results of the examination were then provided to the physicians treating the patients. Vaginosis was diagnosed if at least three of the four Amsel criteria were met. ${ }^{12}$ Samples from both cases and controls were looked for Clue cells, Gram staining and whiff test was done. Nugent scoring and Hay Ison Grading was done to compare both the groups.

A case record form recorded gestational age at inclusion, the reason for hospitalization, parity and examination data (discharge appearance, vaginal $\mathrm{pH}$, and $\mathrm{KOH}$ test) for each patient at the time of the clinical examination. Cases were asked questions about the presence of any fishy odor after have sexual intercourse. The history about the labour onset, type of labour, duration and other events related to labour events were recorded.

\section{Statistical analysis}

Data was entered in Microsoft Excel spreadsheet and analysed using SPSS v 16.0 software. Data were expressed as mean, percentage, and standard deviations. Categorical variables were analysed using Chi-square test. A p-value of $<0.05$ was considered statistically significant at $95 \%$ confidence interval.

\section{Results}

This cross-sectional study 'Role of Bacterial Vaginosis in preterm labour was conducted on 100 randomly selected subjects that were matched with an equal number of Controls for comparative evaluation. Age of Cases was in between 20 and 42 years and their mean age $29.7 \pm 4.2$ years, whereas age of the subjects in the control group were in between 22 and 44 years and their mean age $30.7 \pm 4.4$ years respectively. Majority of subjects in the study and control groups were in between 30 to 34 years which comprised the major proportion of $45.0 \%$ and $54.0 \%$ respectively. This was succeeded by $25-29$ year age group where its proportions were $37.0 \%$ and $29.0 \%$ respectively. Anyhow the difference in age was not significant ( $>0.05$ ) (Table 1).

Socioeconomic status and occupation of the study subjects were compared and found to be statistically significant among cases and controls ( $p>0.05$ ). Nonetheless, as the study was conducted in a city hospital; thereby $55.0 \%$ of cases and $57.0 \%$ among the Control group were urban inhabitants. Occupation was distinguished as unskilled, semiskilled and skilled worker which hold proportion of $48.0 \%, 21.0 \%$ and $31.0 \%$ among the cases respectively; whereas its proportion among the control group was $39.0 \%, 28.0 \%$ and $33.0 \%$ respectively. Literacy rate among the cases was $62.0 \%$ and was significantly low $(\mathrm{p}<0.05)$ alongside the controls among which $76.0 \%$ were literate. Minimum and maximum monthly income of the cases was 1,500 and 20,000 rupees with the mean of Rs. $8675 \pm 6013$ which was significantly low $(p<0.05)$ against the control group whose income varied between 2,000 and 22,000 with the mean of Rs. $9890 \pm 5276$ (Table 2).

All the subjects presented themselves during second and third trimester of pregnancy. Gestation Age (weeks) in the subjects of study group was in between 21 and 36 with the mean of $30.2 \pm 2.8$, whereas Control group subjects were in between 23 and 35 with the mean of $30.2 \pm 2.8$. The difference was not significant ( $p>0.05$ ). Gravida and Parity in the two groups also did not show any significant difference. Cases and control group did differ significantly $(p<0.05)$ for proportionate change in previous history of intra uterine growth retardation 35.4/15.9, Abortions 23.0/0.0 and Pre-Term Delivery 17.0/0.0 (Table 3).

Rational difference $(\mathrm{p}<0.05)$ among clinical characteristics of cases and control group was observed as copious vaginal discharge (32.0/5.0), Premature rupture of membrane (21.0/4.0), Unsatisfactory personal hygiene (20.0/10.0) and Uterine anomalies (10.0/3.0). Moreover history of Smoking was revealed by $4 \%$ subjects in each group, which was insignificant ( $\mathrm{p}>0.05$ ) (Table 3 ).

$\mathrm{pH}$ was abnormal in $26 \%$ cases against $9 \%$ controls. The cases had $\mathrm{pH}$ of $4.6 \pm 1.2$ that was in between 3.8 and 7.5 and was significantly high $(\mathrm{p}<0.05)$ as compared to controls whose $\mathrm{pH}$ was $4.2 \pm 0.3$ with a minimum of 3.8 and a maximum of 4.7 respectively. Whiff Test (20.0), Clue Cells (15.0) and Gram Stain (19.0) were observed among cases only. These led to the median Nugent score of 3 among cases which was significantly high $(\mathrm{p}<0.05)$ against the median score of 1 attained by the controls. Similarly; Hay-Ison Grade III and Grade II among cases was $23.0 \%$ and $14.0 \%$ that did bear significant difference $(p<0.05)$ against respective $0.0 \%$ and $4.0 \%$ as assessed in controls (Table 4). 
Table I Socio-demographic characteristics of the studied subjects (cases and controls)

\begin{tabular}{|c|c|c|c|c|c|c|c|}
\hline \multirow[t]{2}{*}{ Characteristic } & & \multicolumn{2}{|l|}{ Cases } & \multicolumn{2}{|l|}{ Control } & \multirow[t]{2}{*}{ df } & \multirow[t]{2}{*}{$P$ value } \\
\hline & & $\mathbf{n}$ & $\%$ & $\mathbf{n}$ & $\%$ & & \\
\hline \multirow[t]{2}{*}{ Dwelling } & Rural & 45 & 45.0 & 43 & 43.0 & $\mathrm{I}$ & 0.776 \\
\hline & Urban & 55 & 55.0 & 57 & 57.0 & & \\
\hline \multirow[t]{3}{*}{ Occupation } & Unskilled & 48 & 48.0 & 39 & 39.0 & 2 & 0.342 \\
\hline & Semiskilled & 21 & 21.0 & 28 & 28.0 & & \\
\hline & Skilled & 31 & 31.0 & 33 & 33.0 & & \\
\hline \multirow[t]{7}{*}{ Literacy status } & Illiterate & 38 & 38.0 & 24 & 24.0 & 4 & $0.006 *$ \\
\hline & Primary & 6 & 6.0 & 5 & 5.0 & & \\
\hline & Middle & 4 & 4.0 & 5 & 5.0 & & \\
\hline & Matric & 7 & 7.0 & 6 & 6.0 & & \\
\hline & Secondary(I2th) & 18 & 18.0 & 13 & 13.0 & & \\
\hline & Graduate & 17 & 17.0 & 30 & 30.0 & & \\
\hline & Professional/Postgraduate & 10 & 10.0 & 17 & 17.0 & & \\
\hline \multirow[t]{2}{*}{ Literacy status } & Illiterate & 38 & 38.0 & 24 & 24.0 & 1 & $0.033^{*}$ \\
\hline & Literate & 62 & 62.0 & 76 & 76.0 & & \\
\hline \multirow[t]{6}{*}{ Monthly income (Rs) } & $<3500$ & 17 & 17.0 & 9 & 9.0 & 4 & $0.004^{*}$ \\
\hline & 3500 to 5000 & 15 & 15.0 & 8 & 8.0 & & \\
\hline & 5000 to 6500 & 18 & 18.0 & 12 & 12.0 & & \\
\hline & 6500 to 10000 & 14 & 14.0 & 19 & 19.0 & & \\
\hline & 10000 & 36 & 36.0 & 52 & 52.0 & & \\
\hline & mean $\pm S D$ & $\begin{array}{l}8675 \pm 6013 \\
(1500,20000)\end{array}$ & & $\begin{array}{l}9890 \pm 5276 \\
(2000,22000)\end{array}$ & & & \\
\hline
\end{tabular}

*p value $<0.05$ statistically significant

Table 2 Maternal characteristics of the studied subjects (cases and controls)

\begin{tabular}{|c|c|c|c|c|c|c|c|}
\hline \multirow[t]{2}{*}{ Characteristic } & & \multicolumn{2}{|l|}{ Cases } & \multicolumn{2}{|l|}{ Control } & \multirow[t]{2}{*}{ df } & \multirow[t]{2}{*}{ P value } \\
\hline & & $\mathbf{n}$ & $\%$ & $\mathbf{n}$ & $\%$ & & \\
\hline \multirow[t]{3}{*}{ Gestation age } & 2nd trimester & 3 & 3.0 & 8 & 8.0 & 1 & 0.756 \\
\hline & 3rd trimester & 97 & 97 & 92 & 92.0 & & \\
\hline & (mean $\pm \mathrm{SD}$ ) wks. & $\begin{array}{c}30.2 \pm 2.8 \\
(21,36)\end{array}$ & & $\begin{array}{l}30.0 \pm 2.9 \\
(23,35)\end{array}$ & & & \\
\hline \multirow[t]{4}{*}{ Gravida } & I & 30 & 30.0 & 35 & 35.0 & 3 & 0.499 \\
\hline & 2 & 47 & 47.0 & 45 & 45.0 & & \\
\hline & 3 & 19 & 19.0 & 13 & 13.0 & & \\
\hline & 4 & 4 & 4.0 & 7 & 7.0 & & \\
\hline \multirow[t]{3}{*}{ Parity } & 0 & 35 & 35.0 & 35 & 35.0 & 3 & 0.258 \\
\hline & I & 56 & 56.0 & 44 & 44.0 & & \\
\hline & 3 & 0 & 0.0 & 7 & 7.0 & & \\
\hline \multirow[t]{2}{*}{ Previous $\mathrm{H} / \mathrm{O}$ intra uterine growth retardation } & Yes & 23 & 35.4 & 10 & 15.9 & 1 & $0.012^{*}$ \\
\hline & No & 42 & 64.6 & 53 & 84.1 & & \\
\hline \multirow[t]{2}{*}{ Abortions } & No & 77 & 77.0 & 100 & 100.0 & 1 & $<0.001 *$ \\
\hline & Yes & 23 & 23.0 & 0 & 0.0 & & \\
\hline \multirow[t]{2}{*}{ Pre-term delivery } & No & 83 & 83.0 & 100 & 100.0 & I & $<0.001 *$ \\
\hline & Yes & 17 & 17.0 & 0 & 0.0 & & \\
\hline
\end{tabular}

${ }^{*} \mathrm{p}$ value $<0.05$ statistically significant

Citation: Shaw T, Saleem SM, Mir S, et al.A study of role of bacterial vaginosis in preterm labour. AdvTissue Eng Regen Med Open Access. 20I8;4(3):64-69. DOI: 10.15406/atroa.2018.04.00080 
Table 3 Maternal characteristics of the studied subjects (cases and controls)

\begin{tabular}{|c|c|c|c|c|c|c|c|}
\hline \multirow[t]{2}{*}{ Characteristic } & & \multicolumn{2}{|c|}{ Cases } & \multicolumn{2}{|c|}{ Control } & \multirow[t]{2}{*}{ df } & \multirow[t]{2}{*}{$P$ value } \\
\hline & & $\mathbf{n}$ & $\%$ & $\mathbf{n}$ & $\%$ & & \\
\hline \multirow[t]{2}{*}{ Vaginal discharge } & Scanty & 68 & 68.0 & 95 & 95.0 & I & $<0.00 I^{*}$ \\
\hline & Copious & 32 & 32.0 & 5 & 5.0 & & \\
\hline Premature rupture of & No & 79 & 79.0 & 96 & 96.0 & I & $<0.001 *$ \\
\hline membrane & Yes & 21 & 21.0 & 4 & 4.0 & & \\
\hline \multirow[t]{2}{*}{$\mathrm{H} / \mathrm{O}$ smoking } & No & 96 & 96.0 & 96 & 96.0 & I & 1 \\
\hline & Yes & 4 & 4 & 4 & 4.0 & & \\
\hline \multirow[t]{2}{*}{ Personal hygiene } & Satisfactory & 80 & 80.0 & 90 & 90.0 & I & $0.048^{*}$ \\
\hline & Not satisfactory & 20 & 20.0 & 10 & 10.0 & & \\
\hline \multirow[t]{5}{*}{ Uterine anomalies } & Normal & 90 & 90.0 & 97 & 97.0 & 3 & $0.046^{*}$ \\
\hline & Bicornuate uterus & 4 & 4.0 & 0 & 0.0 & & \\
\hline & Fibroid uterus & 3 & 3.0 & 3 & 3.0 & & \\
\hline & Cervical & 3 & 3.0 & 0 & 0.0 & & \\
\hline & Incompetence & & & & & & \\
\hline
\end{tabular}

$*_{p}$ value $<0.05$ statistically significant

Table 4 Investigation profile of the studied subjects (cases and controls)

\begin{tabular}{|c|c|c|c|c|c|c|}
\hline \multirow[t]{2}{*}{ Characteristic } & & \multicolumn{2}{|l|}{ Cases } & \multicolumn{2}{|l|}{ Control } & \multirow{2}{*}{$\begin{array}{l}\text { P } \\
\text { value }\end{array}$} \\
\hline & & $\mathbf{n}$ & $\%$ & $\mathbf{n}$ & $\%$ & \\
\hline \multirow[t]{3}{*}{$\mathrm{pH}$} & Raised & 26 & 26.0 & 9 & 9.0 & $0.002^{*}$ \\
\hline & Normal & 74 & 74.0 & 91 & 91.0 & \\
\hline & (mean $\pm S D)$ wks. & $\begin{array}{l}4.6 \pm 1.2 \\
(3.8,7.5)\end{array}$ & & $\begin{array}{l}4.2 \pm 0.3 \\
(3.8,4.7)\end{array}$ & & \\
\hline \multirow[t]{2}{*}{ Whiff test } & Negative & 80 & 80.0 & 100 & 100.0 & $<0.00 I^{*}$ \\
\hline & Positive & 20 & 20.0 & 0 & 0.0 & \\
\hline \multirow[t]{2}{*}{ Clue cells } & Absent & 85 & 85.0 & 100 & 100.0 & $<0.00 I^{*}$ \\
\hline & Present & 15 & 15.0 & 0 & 0.0 & \\
\hline Gram & Nil & 81 & 81.0 & 100 & 100.0 & $<0.00 I^{*}$ \\
\hline Stain & Positive & 19 & 19.0 & 0 & 0.0 & \\
\hline Nugent score (median) & & $3(0,8)$ & & I $(0,5)$ & & $<0.00 I^{*}$ \\
\hline Hay Ison & Grade I & 63 & 63.0 & 96 & 96.0 & $<0.00 I^{*}$ \\
\hline \multirow[t]{2}{*}{ Grade } & Grade II & 14 & 14.0 & 4 & 4.0 & \\
\hline & Grade III & 23 & 23.0 & 0 & 0.0 & \\
\hline
\end{tabular}

$*_{p}$ value $<0.05$ statistically significant

\section{Discussion}

The aetiology of preterm labour is multiple and poorly understood. Some obstetrical conditions are more or less obvious, while in many cases the pathophysiological mechanisms are still unknown. With the advanced medical facilities, the survival frequency of premature neonates with very low birth weights has increased considerably. In our investigation we found, pregnant women in the age group of 20 and 42 years (mean age $29.74 \pm 4.2$ years. Most of the subjects among the cases and control groups were in the age group of 30-34 years. There was no statistical significance seen with bacterial vaginosis and age. Bhalla $\mathrm{P}$ et al., ${ }^{13}$ carried out of an investigation and found no relationship between presence of bacterial vaginosis with age. These finding are in accordance with our study.

Most of the population (77\%) of the Kashmir division belong to rural areas. In this study, the patients were mostly from the urban set up $(55 \%)$. This may be due to the fact that the said hospital is the lone tertiary care hospital in the Kashmir valley and most of the private hospitals and clinics refer patients to the said hospital. The predominance of Bacterial vaginosis was found mostly among women belonging to urban areas $(55 \%)$. Similar finding were reported 
by Bhalla $\mathrm{P}$ et al., ${ }^{13}$ who discovered $38.3 \%$ predominance of bacterial vaginosis in urban areas $28.8 \%$ and $25.4 \%$ in urban white-collar class.

We found an association between Bacterial Vaginosis and low education level and low income. Literacy rate in the study group was $62.0 \%$ and was significantly low $(p<0.05)$ than the controls among which $76.0 \%$ were literate. Inspite of the fact that major chunk of the patients were referred from the periphery (Rural area) occupation was distinguished as skilled, semi-skilled and unskilled. Mostly the unskilled group was found to be illiterate or were having primary education level (Table 2 depicting socio demographic profiles).

Minimum and maximum monthly income of our study group subjects was Rs 1,500 and 20,000. With the mean of $8675+6013$ which was significantly low $(p<0.05)$ than the control Group whose income varied between 2,000 and 22,000 with the mean of 9890+5276. Jones FR et al., ${ }^{14}$ found a $27 \%$ prevalence of bacterial vaginosis in women with low monthly income. These findings are in accordance with our findings.

The existences of certain genital microflora's have been related with expanded hazard for rashness. In our investigation, one instance of gonorrhoea $\mathrm{a}^{3,10,15}$ was observed to be available that was affirmed by Grams staining (gram-negative diplococci). No persuading proof bolstered a relationship amongst $T$. Vaginalis and rashness. ${ }^{15}$ Though we had few cases (in study and control group) as positive for trichomoniasis however not a relationship for Preterm Labour. Abnormal amounts of Gardenella/Mobiluncus species/Curved Grampositive rods were available in $21 \%$ cases and bacteriods in a single case related with both preterm work and preterm conveyance. ${ }^{7,16,17}$ Mobiluncus species were profoundly particular for instances of bacterial vaginosis. McGregor et al. ${ }^{18}$ revealed that for ladies with bacterial vaginosis who additionally had Mobiluncus morphotypes distinguished by Grams staining, the relative danger of Preterm work was considerably higher than for women with Bacterial Vaginosis without the living beings. Moreover, Gravet et al., ${ }^{19}$ detailed recuperation rates of $T$. vaginalis among ladies with preterm work. All the above investigations are as per our examination.

In this examination we found, bacterial vaginosis more typical among pregnant patients hospitalized for preterm work between 28 34 weeks of gestation in regard to the control group hospitalized for different reasons at a comparable gestational age. We pick Amsel's clinical criteria ${ }^{12}$ to analyse bacterial vaginosis due to its wide recognisability and utilization all over the globe.

One important finding of this study has been the finding a relationship between the presence of bacterial vaginosis and preterm labour. Conveyance of a low birth weight new-born child in the women's first pregnancy was the factor most emphatically connected with the unexpected labour of such a baby in the present pregnancy.

History of unconstrained premature births (cervical inadequacy) was found because of bacterial vaginosis in $23.0 \%$ cases in the investigation. Gravida and parity also did not show any significant difference for occurrence of bacterial vaginosis. The study/control group did differ significantly for proportionate change in previous history of delivery of low birth weight infants, abortions and preterm delivery.

Rational difference among clinical characteristics of the study/ control subjects was observed as copious malodorous vaginal discharge, premature rupture of membranes, unsatisfactory personal hygiene and uterine anomalies. Moreover H/O smoking was revealed by $4 \%$ subjects in each group, which was insignificant. Investigation profile showed significantly high vaginal $\mathrm{pH}$ in study cases, positive wifftest, clue cells, Grams staining done in cases led to the Nugent score of 3 which was significantly high against the median score of 1 attained by controls. Similarly Hay/Ison grade-iii and grade-ii among cases did bear significant difference as assessed in controls for confirmation of Bacterial vaginosis.

Gardenerella/Bacteriods/Mobiluncus morphotypes and curved gram variable rods (gram negative rods) were found to be significantly present in the specimens of studied cases as a cause of bacterial vaginosis infection.

Bacterial Vaginosis is the most common vaginal disorder seen in women of reproductive age. The main complaint of women with this condition is a malodorous vaginal discharge. Women had a copious malodorous vaginal discharge $32 \%$ cases in our study. However many women with demonstrable signs have no symptoms. This was found to be associated with women with unsatisfactory personal hygiene in $20 \%$ of our study cases. ${ }^{1,3,16}$

The Presence of Bacterial Vaginosis in middle and late gestation has been associated with preterm delivery. ${ }^{2,410,15}$ The microfloras involved in Bacterial Vaginosis is a risk factor for prematurity. Bacterial Vaginosis is also associated with infection of the chorioamnion. ${ }^{15,18}$ In the present study, Bacterial Vaginosis was significantly associated with preterm delivery and premature rupture of membranes prior to 37 wks of gestation. A total of 21 cases were admitted with an $\mathrm{H} / \mathrm{O}$ premature rupture of membranes and were found to be positive for bacterial vaginosis. This was supported by the study conducted by Parwan M, Ughades and found that Bacterial vaginosis diagnosed in second trimester was associated with an increased risk of preterm delivery and premature rupture of membranes and accounted for $83 \%$ of the attributable risk for prematurity.

In our study, we found no association between prevalence of bacterial vaginosis and smoking as there were 4 hukka smokers in our study as well as 4 hukka smokers in the control group. Association between prevalence of Bacterial Vaginosis and smoking was also not found in a study conducted by Bhalla $\mathrm{P}$ et al., ${ }^{13}$ as the number of smokers was very few in their study.

This was in accordance with our study. In the present study bacterial vaginosis (Nugent Score $>7$ Hay/ Ison grade-3) was found in $23 \%$ cases and intermediate flora (Nugent score 4-6/Hay Ison grade-2) was observed in $14 \%$ cases.

\section{Conclusion}

We conclude that bacterial vaginosis is common among women with unsatisfactory personal hygiene, low literacy rate, poor socioeconomic background and who have previous history of abortions, premature rupture of membrane and history of preterm labour in the previous pregnancy. Furthermore, Gardnerella Vaginalis, Mobiluncus morphotypes, bacteriods spps and Gonococci are the commonly found organisms in women with bacterial vaginosis. It is recommended that screening and treatment of asymptomatic infections should be performed early in the pregnancy so that the complication rate can be decreased and normal pregnancy outcome achieved. 


\section{Acknowledgements}

Authors would like to thanks Department of Gynaecology and Obstetrics, Government Medical College, Srinagar for their cooperation and support during the process of study. We would like to thank and acknowledge the contribution of Dr. Sheikh Mohd Saleem towards the editing, compiling, data interpretation and Statistical analysis of this manuscript.

\section{Conflict of interest}

The author declares no conflict of interest.

\section{References}

1. Ison CA, Hay PE. Validation of a simplified grading of gram stained vaginal smears for use in genitourinary medicine clinics. Sex Transm Infect. 2002;78(6):413-415.

2. Hay PE. Therapy of bacterial vaginosis. J Antimicrob Chemother. 1998;41(1):6-9.

3. Martin DH, Koustsky L, Eschenbach DA, et al. Premature and perinatal most in pregnancies complicated by maternal C. trachomatis infections. JAMA. 1982;247:1585-1588.

4. Nugent RP, Krohn MA, Hillier SL. Reliability of diagnosing bacterial vaginosis is improved by a standardized method of Gram stain interpretation. J Clin Microbol. 1991;29(2):297-301.

5. Berkowitz GS. An epidemiologic study of preterm delivery. Am J Epidemiol. 1981;113(1):81-92.

6. French JI, McGregor JA. The pathobiology of premature rupture of membranes. Semin Perinatol. 1996;20(5):344-368.

7. ACNM Clinical Bulletins. American College of Nurse-Midwives. Clinical bulletin no. 4-December 1998 Bacterial vaginosis in pregnancy. J Nurse Midwifery. 1999;44(2):129-134.

8. Caro Paton I, Carvajal A, Martin de Diego I, et al. Is metronidazole teratogenic? A meta-analysis. Br J Clin Pharmacol. 1997;44(2):179-182.
9. Morales WJ, Schorr S, Albritton J. Effect of metronidazole in patients with preterm birth in preceding pregnancy and bacterial vaginosis: a placebo-controlled, double-blind study. Am J Obstet Gynecol. 1994;171(2):345-347.

10. Andrews WW, Goldenberg RL, Hauth JC. Preterm labour: emerging role of genital tract infections. Infect Agents Dis. 1995;4(4):196-211.

11. Gazi H, Degerli K, Kurt O, et al. Use of DNA hybridization test for diagnosing bacterial vaginosis in women with symptoms suggestive of infection. APMIS. 2006;114(11):784-787.

12. Amsel R, Totten PA, Spiegel CA, et al. Nonspecific vaginitis. diagnostic criteria and microbial and epidemiological associations. Am J Med. 1983;74(1):14-22.

13. Bhalla P, Chawla R, Garg S, et al. Prevalence of bacterial vaginosis among women in Delhi, India. Indian J Med Res. 2007;125(2):167-172.

14. Jones FR, Miller G, Gadea N, et al. Prevalence of bacterial vaginosis among young women in low-income populations of coastal Peru. Int $J$ STD AIDS. 2007;18(3):188-192.

15. Alger LS, Lovchik JC, Hebel JR, et al. The association of C. Trachomatis, Neisseria gonorrhoeae, and group B streptococci with preterm rupture of membranes and pregnancy outcome. Am J Obstet Gynecol. 1988;159(2):397-404.

16. Briseldon AM, Hillier SL. Evaluation of Affirm VP microbial identification test for Gardnerella Vaginalis. $J$ Clin Microbial. 1994;32(1):148-152.

17. Watts DH, Eschenbach DA, Kenny GE. Early Postpartum endometritis; genital mycoplasmas, and Chlamydia trichromatic. Obstet Gynecol. 1989;73(1):52-60.

18. McGregor JA, French JI. Bacterial vaginosis in pregnancy. Obstet Gynecol Surv. 2000;55(5 Suppl 1):S1-S19.

19. Gravet MJ, Hummel DG, Eachenbach DA. Preterm labour associated with subclinical amniotic fluid infection and bacterial vaginosis. Obstet Gynecol. 1986;67(2):229-237. 